\title{
Methods to Oral English Practice
}

\author{
Liangguang Huang \\ English Department, Zhenjiang Watercraft College of PLA \\ Zhenjiang 212003, China \\ E-mail: Blackhawk1975@126.com
}

\begin{abstract}
In recent years, the people wake up gradually that oral English takes an important position in communication. According to College English Curriculum Requirements, the objective of College English is to develop students' ability to use English in a well-rounded way, especially in listening and speaking. The basic requirement of oral English is that students should be able to communicate in English in the course of learning, to conduct discussions on a given theme, and to talk about everyday topics in English. They should be able to give, after some preparation, short talks on familiar topics with clear articulation and basically correct pronunciation and intonation. They are expected to be able to use basic conversational strategies in dialogue. In order to improve oral English, the students should use some effective approaches to practice.
\end{abstract}

Keywords: Oral English, Speaking, Listening, Recitation

\section{Introduction}

For a long time, the English learners, especially the college students, spent most of their time reading, writing and translating. After graduation, some of them found surprisingly that they couldn't communicate with foreigners freely. In recent years, the people wake up gradually that oral English takes an important position in communication. According to College English Curriculum Requirements, the objective of College English is to develop students' ability to use English in a well-rounded way, especially in listening and speaking. The basic requirement of oral English is that students should be able to communicate in English in the course of learning, to conduct discussions on a given theme, and to talk about everyday topics in English. They should be able to give, after some preparation, short talks on familiar topics with clear articulation and basically correct pronunciation and intonation. They are expected to be able to use basic conversational strategies in dialogue.

With the rapid development of globalization, the communication with the foreigners is more frequent. How to train our learners to acquire competence in oral English to meet the urgent need of our country is a great challenge that confronts and puzzles us English teachers very much. Here I take the liberty to offer some ideas about practicing oral English, hoping that it will help English learners a little, and that language experts will kindly and generously give their good advice on it.

To learn to practice a second language is more or less like learning to practice our own language. Take our children in their Chinese learning situation for instance, when they begin their language study, they undergo an indispensable process of recognizing the sounds, phrases, sentences made by their parents and persons around imitating, internalizing the meanings, memorizing, thinking (having found out some rules), making sentences as simple as they can to express themselves. They learn hard to use the language; otherwise, they will fail to communicate or to get things they want. But to Chinese adult and younger English learners, the language environment differs from that of Chinese infants' learning their own language. What they rely on are only books, English teachers, tapes and TV programs. So if you want to practice your English orally, the only way is to listen to more, to read more, to put what you have learnt into practice, to create an English atmosphere, to elaborate your approaches and to get every inch of time to use it if possible, so as to increase your competence in a limited time, though some stages a native speaker must experience are omitted.

\section{Some approaches to Oral English Practice}

\subsection{Close connection between listening and speaking}

As an English learner, you should know the close connection between listening and speaking. They are compared to being as inseparable as fish and water, co-existing in language learning. As a rule, in any language learning, listening comes first, followed by imitating, speaking, etc. A dumb or mute person can not, of course, speak just because of his failure of audibility. If you want to speak English, you should, above all, concentrate 
yourself on listening to native speakers that can help you a lot in both correcting your pronunciation and intonation mistakes and fortifying your aural comprehension. Only by listening to more, can you imitate and get to catch what a speaker says or have a better understanding of what a movie tells. While you are listening to something, you imitate it, absorb it or even digest it and make it a sort of nutrition in your English language learning, with which you can use in your practice.

If you want to develop your speaking ability, you had better do much more painstaking work with perseverance. First, listen to some longer conversations, stories recorded or reports given by native speakers, then, give the outlines. Through years' effort, you can tell in detail what you have listened to. The more you can retell, the greater your speaking ability is enhanced.

Provided you listen to less, speak less, and your pronunciation and intonation are bad, how can you have a talk or exchange your ideas in English with other learners or English speakers?

Listening leads you to speaking. Good pronunciation and intonation plus idiomatic expressions can convey your ideas clearly. Good pronunciation and intonation plus excellent aural comprehension and marvelous proficiency can bring you to successful communications.

\subsection{Apply what you have learnt to practice}

For an English learner, it is very important to apply what you have learnt to practice. When you meet other learners or native speakers, try to open your mouth and talk with them in English, from simple sentences to complicated sentences, by and by. Never be frightened to ask questions if you do not understand. Those who have taken the course of Junior English for China appear to be very eloquent after having been strictly trained when you talk with them about the contents of the textbook. Teaching method is one thing which can not be neglected admittedly while self challenge is another - a more decisive factor to a certain extent. If you persist in doing so, you may find you can make progress with big strides in a short time. Listen to more, read more and precise more. Accumulate your knowledge by reading and test your competence by practicing. Reading is learning, practicing is also learning and more important at that.

\subsection{Recitation of English poems, proses, etc.}

Recitation of English poems, proses, or even short stories, in which there is large vocabulary and many useful expressions, is also an effective way in strengthening oral English. Here is a story about my cousin's Chinese recitation experience. After liberation his first school year was at a private school where my uncle simply taught them beginners Chinese classics - The Great Learning, The Analects of Confucius, Mencius and The Doctrine of the Mean, etc., without giving any explanation and analysis. The pupils were only asked to recite the books given and to recognize the Chinese characters in them and to practice calligraphy. Dull as it was, he had to shoulder the heavy burden reluctantly. If he failed to accomplish this, my uncle would scold him and punish him with a bamboo ruler. He did it very well anyhow, and thus avoided the ruthless slashes. Later he found recitation very useful and helpful, for it laid him a solid foundation in his Chinese language. He towered over his classmates in this subject and even surpassed his primary school teachers in recognizing different Chinese characters. By the time he was at junior school and high school, he came to know the abstruse meanings implied in the books and could quote from and use them into his compositions appropriately. The importance of recitation should be emphasized, but the severe attitude of my uncle towards the pupils should be repudiated.

Some old scholars also told about their English study experience in certain missionary schools where their foreign teachers were very conscientious for work and strict with the students. Recitation of English poems, proses, essays, and sometimes even short stories was among the heavily demanded tasks and assignments. As a result, part of the students who were diligent in recitation stood out from their classmates in English. Some of them can now still surprisingly recite many poems, proses, essays, short stories such as A Little Match Girl, The Gettysburg Speech, etc. New expressions are derived from old ones. In this sense, recitation can give you a stick in both English writing and oral English. The more you recite, the more you have learnt till you can use English effectively and accurately. It is something like drops of rain that can wet language-learning trees green.

\subsection{Various topics training}

Do not stick yourself to the clichés such as "How old are you?", "How many members are there in you family?", "What is your father?" etc. To shift your topics one after another when you are familiar with the previous one is a reasonable approach to your set goal. But when you have a new topic, you should get yourself well prepared in advance. Each time you have many new things to learn and will have learnt a lot when the topic is over. Practicing so over a long period, you are certain to have covered a wide range of subjects including science, technology, literature, arts, etc. Your knowledge is enlarged; your vocabulary is widened; your competence is 
increased without your knowing it. Step by step, you will progress from a mere English lover to a skilled and gifted interpreter.

\subsection{To create an English environment}

For both students and teachers, the value of creating a good language environment should not be underestimated. In order to understand the language, you should speak English in and outside class and take an active part in all kinds of English activities, you should join an English corner or a similar club, and you can label your furniture in your house with English words, too. Furthermore, you should bring a small Chinese-English dictionary or an English-Chinese dictionary with you for your reference.

Do not be afraid to make mistakes or errors when you have a talk in English. In the world there is only one kind of persons who do not make any mistakes just because they do not do anything and can not do anything at all. Mistakes and errors are often the guide to correctness and accuracy. This time you make a mistake or an error, next time you will be in the high vigilance against it. Tested by failures and frustrations, you can finally stand on your own feet with the ability to use fluent English. "Practice makes effective" is the reward you deserve.

\subsection{To think in English}

You would be confused by the words of your teacher "Think in English when you study the language" and perhaps you will say "How can that be?" There is little exaggeration and astonishment to experienced learners. If any one wants to command this language, he should think in English. This is an irrefutable truth. Put aside your own language environment, you are assumed to live in an English-spoken country such as the United States, Britain, Canada, etc. The people you meet are all English speakers. What will you do then? You want to make a living, you want to communicate with them, and you want to develop your career. The only alteration for you is not to use your gestures all the time but to use the little English you have learnt. The given situation demands that you should express yourself in English and learn more and practice more; otherwise, you are likely to live on an isolated island. Your native language seems to be of no use and you should cultivate yourself with a new language - English. Once you get into the habit of thinking in English, you have acquired the ability of expressing yourself in English.

At the same time you are a person who actually lives in China. When your countrymen speak Chinese, you can also take the advantage by interpreting what they say into English in a whisper. It is a way to train your fluency and sensibility for your English thinking.

\section{Conclusion}

There are no universal ways that suit everyone in their learning. You may choose the ones that most satisfy your craving for English practice. The approaches or shortcuts differ with different persons.

All in all it is motivation which has the larger effect on English language learning rather than individual language ability.

\section{References}

Advanced Education Department of Ministry of Education. (2007). College English Curriculum Requirements. Beijing: Tsinghua University Press.

Council of Europe. (2001). Common European Framework of Reference for Languages: Learning, teaching, assessment. 